\title{
The Royal Hunt of the Sun: Peter Shaffer and the Quest for God
}

\author{
Maite de Ituarte \\ Universidad de Deusto
}

\begin{abstract}
This paper wishes to establish how Peter Shaffer's great subject in his later plays and very particularly in The Royal Hunt of the Sun is the quest for some kind of god. The aging and spiritually depleted Pizarro embarks on a military and economic expedition which turns into a last-ditch spiritual quest for the Sun God Atahuallpa. After discussing the source for the play and the possible influence of Eugene O'Neill and Antonin Artaud, the essay goes on to demonstrate that god-hunting supplies the dramatic structure for Shaffer's masterpiece and that the multiplicity of gods is the source of dramatic conflict within the structure. It often seems as if Shaffer actually would like to believe that his dramas reflect a battle of wills between a role-player and a person who is so unstructured and unrestricted that he is literally a primitive. In The Royal Hunt of the Sun, Shaffer is able to realize his dream and begins to associate the ritual with the primitive characters found in the play. Through the ritual, Pizarro is able to mature and, for the first time in his life, he learns how false his life has been. By his nonrealistic intermingling of space and time, Shaffer forces his audiences to embark on a god-hunt along with his characters.
\end{abstract}

Theatre goers who were familiar with the realistic style of Shaffer's early dramas found it difficult to recognize Shaffer as the author of The Royal Hunt of the Sun. After all, primitive dances, «savage music,» bird cries, and Incan sign language are far removed from the British tea room. The Royal Hunt of the Sun is the first of Shaffer's plays to deviate from the well-made play tradition. However, the content is consistent with the ideas presented in his earlier dramas. The only difference is that in The Royal Hunt of the Sun the conflict between the role-player and his alter ego goes beyond a criticism of how people prevent the blossoming of the human will, and, for the first time, the dialectic includes an attack on institutionalized power. The sexual conflict is still a personal one, but it has now been expanded to include the «rape» of one country by another.

Compared to Beckett, Pinter, and Stoppard, who may be considered as postmodernist playwrights in terms of their self-reflexive attitude towards form, Shaffer does appear as «traditional.» That is, he belongs rather to the tradition of modernism that was established in the American theatre of the twenties, and unlike Pinter, 
Beckett, and other dramatists whose elliptical dialogue has shaped the contemporary theatre, Shaffer is given to sustained and flowing oratory.

Peter Shaffer is the playwright now writing in English who most reminds us of Eugene O'Neill. «Most modern plays are concerned with the relation between man and man," O'Neill once remarked in conversation, «but that doesn't interest me at all. I am interested only in the relation between man and God.. ${ }^{1}$ Like O'Neill, Shaffer experiments with such devices as the split protagonist (The Great God Brown, Equus), masks, mime and spectacle (Lazarus Laughed, The Royal Hunt of the Sun), and the extended monologue as a means of revelation (The Iceman Cometh, Shrivings, Amadeus). Like O'Neill, Peter Shaffer avoids the bare settings and minimalist abstractions of the Theatre of the Absurd. Furthermore, for many of the postmodernists, God, philosophy, and religious institutions are no longer a matter of concern so much as it is a foregone conclusion, but this is not the case with Shaffer who seems to be obsessed with man's longing for divinity. The religious quest is prominent throughout his work. In The Royal Hunt of the Sun, the Spanish conquest of Peru serves him as the setting for a clash between Catholic and Pagan visions of the world, and the play is concerned only incidentally with the rape and massacre of the Incan civilization by the Spanish conquistadores. Equus is only peripherally related to the pitfalls of modern psychiatry, and Shaffer is really discussing the idea that modern life destroys our capacity for union with divinity, while in Amadeus the main subject is that man's disillusionment with God can poison the relation of the self to others.

In Shaffer's work man talks to God but is answered only by his silence. During that extended silence, the monologue turns back upon the speaker and his memories, uncovering the fragmentary nature of his being. And a third term appears above the debate to which the characters appeal in vain, an absent mediator: the silent God. Shaffer's voluble, god-driven protagonists' soliloquies on the silence of divinity have indeed electrified the contemporary stage. Protagonists such as Pizarro, Dysart, and Salieri who in the end remain spiritually and metaphysically isolated.

Peter Shaffer is perhaps the most imaginative playwright writing for today's stage. A master of prose, he is quite an expert at balance and antithesis, sonorous rhythm, epigramatic precision, and every variety of figurative speech. Words in Shaffer's plays aspire to the condition of music, which for Shaffer seems to be the supreme art. It is interesting to note that characters in his plays complain that language is an unsatisfactory means of communication. Thus in The Private Ear, Ted has «a gift for words,» but Bob, who is more sensitive, loves music. Therefore, it is not surprising that music is featured prominently in most of Shaffer's plays whether as background sound or as part of the plot. The climax of this progression occurs in Amadeus, as fragments of Mozart's music fill the theatre. Salieri, who knows better than anyone what he is hearing, states quite simply that "music is God's art.» ${ }^{2}$ Later in the play Mozart will argue with conviction that playwriting compares unfavourably with opera, perhaps giving us a clue to Shaffer's attitude towards dialogue:

That's why opera is important, Baron. Because it's realer than any play. A dramatic poet would have to put all those thoughts down one after another to represent this second of time. The composer can put them all down at once -and still make us hear each one of them (II, p. 66). 
The source for The Royal Hunt of the Sun is William Prescott's The Conquest of Peru, a book Shaffer read while bed-ridden. ${ }^{3}$ To dramatize Prescott's history on stage, Shaffer turned to some modern theorists of drama. For the first time in his career, Shaffer pays homage to Genet. At the end of the Introduction to The Royal Hunt of the Sun, he remarks

Pizarro recovers the savour a little, very little ... But in no very paradoxical sense he recovers joy, by finding real grief. The frost melts. As Genet said: «To see the soul of a man is to be blinded by the sun» (viii). ${ }^{4}$

The discovery of Genet probably led Shaffer straight to Artaud who in Le theatre et son double outlined the staging of The Conquest of Mexico, a spectacle that was to be the first production of his Theatre of Cruelty. ${ }^{5}$ Although Artaud had planned to dramatize the relationship between Cortez and Montezuma, it is possible that Shaffer used Artaud's plan as an outline for what he might try to do with Prescott's book. To delineate clearly the differences between Pizarro and Atahuallpa, Shaffer turned to ritual theatre. In The Royal Hunt of the Sun, the ritual helps to distinguish the difference between the true freedom of the Inca and the restricted status of the roleplayer. It therefore aids in establishing a more meaningful sort of communication between the two leaders than any direct confrontation could provide. Shaffer, then, is essentially reducing theatre to the type of communication so cherished by Artaud. Ritual is frequently a viable means of social communication that can convey a number of social mores. Shaffer says, «My hope was always to realize on stage a kind of 'total' theatre, involving not only words, but rites, mimes, masks and magics» (x). ${ }^{6}$ Artaud immediately comes to mind, specially his comment on how he would stage his version of The Conquest of Mexico:

Ces images, ces mouvements, ces danses, ces rites, ces musiques, ces mélodies tronquées, ces dialogues qui tournent court, seront soigneusement notés et décrits autant qu'il se peut avec des mots.?

In The Royal Hunt of the Sun, dialogue is frequently replaced by gestures, particularly appropiate in the context of Shaffer's play, since sign language is the only means of communicating between the Spanish and the Incas. Masks are used to reduce artificial emotions, and white ligths are varied to produce what Artaud might call the qualities of particular musical tones. Mime is present in the Indian harvest (I.6, p. 30), ${ }^{8}$ the ascent of the andes (I.8, p. 37), the massacre of the Incas (I.12, p. 50), the dance that Atahuallpa shows Pizarro (II.5, p. 66), and the Gold Procession and «Rape of the Sun» scene (pp. 62, 67). There are twenty one musical interludes that include everything from Indian laments to a full-scale musical procession into Cajamarca. And to accompany the music and dance, there are numerous cries (I.4), savage music (I.7; I.12; II.8), tropical bird cries and «low-menacing chants» (II.9). When all these effects are absorbed as one choreographed rhythm, they provide a symbolic sort of communication that is, as Artaud hoped, unconsciously transmitted.

The religious quest is prominent throughout Shaffer's work, and despite the compelling settings, each of his masterpieces is really an exploration of man's search for gods, what he does when he seems to find them, and how ultimately elude him. 
The quest for God is indeed Shaffer's great subject in The Royal Hunt of the Sun, and it is this quest for God that supplies the dramatic structure while the multiplicity of gods is the source of dramatic conflict within this structure. The names Shaffer gives to the two acts of the play disclose its essential structure. Act I is called «The Hunt,» and act II «The Kill.» This is a simple formula indeed which shows an extended search for a god, and, ironically, the god's murder when he is found. Pizarro embarks on a military and economic expedition which turns into a last-ditch spiritual quest for the Sun God Atahuallpa. Yet when Atahuallpa is found, he is destroyed.

Pizarro, a figure of despair who mistrusts his own religion, is enticed by the release of worship promised by the Incan rites. However, though he binds himself spiritually -and literally, by rope, at one point of the play- to Atahuallpa, the Incarnate Sun God, he cannot maintain the union. What most attracts Pizarro to the Inca is the latter's preternatural equanimity, not his creed. We know that Pizarro despises organized religion: «Dungballs to all churches that are or ever could be! How I hate you» (I.2, p. 22). Yet he hungers for a release from inner turmoil and thus is drawn with fascination to the Incan God King, a man whose gestures resonate with such imperturbable grace, and Pizarro is all the more impressed with Atahuallpa's bold assertion «I need no one» (II.4, p. 61) with which he almost convinces Pizarro, the arch-skeptic, of his sacred power, and makes him explain: «He has some meaning for me, this man-God. An immortal man in whom all his people live completely" (II.3, p. 56). In turn, Atahuallpa willingly extends his personal embrace to the conquistador "Believe in me. I will give you a word and fill you with joy. For you I will do a great thing. I will swallow death and spit it out of me» (II.11, p. 87). If Pizarro for a moment is tempted to believe in the possibility of resurrection, it is not because a pagan eschatology seems inherently more reasonable to him than a Christian one. He is amazed by the completeness of Atahuallpa's character, his inner unity: «It is the only way to give life meaning! To blast out of time and live forever, $u s$, in our own persons!» (II.11, p. 86). We see Atahuallpa free and hovering god-like over the play's action in Act I, scenes iii-vii. However, in the final scene of Act II he is sacrified dying a painful human death. He has cheated Pizarro of his dreams and left singing the Sun God's song which includes the line "the trap is set, $O$ little finch.»

Adding irony and complication, Shaffer gives both his pagan (Atahuallpa) and his atheist (Pizarro) attributes of Jesus Christ. Atahuallpa's Chief informs Pizarro that Atahuallpa «needs no wedded mother. He is God» (I.4, p. 25). The Chief continues: «Atahuallpa is his [the Sun's] child sent to shine on us for a few years of life. Then he will return to his father's palace and live forever,» and the Spaniards have the Indians repeat: «Jesus Christ Inca» (p. 26). Pizarro himself first quietly evokes Atahuallpa as if he were the promised Messiah: «Send him, send him, send him, send him ... You're coming. Come on then! Come on!» (I.11, p. 46-47). As the play moves towards its sacrificial conclusion, the links between Atahuallpa and Christ are even more explicit. Atahuallpa anounces that he is thirty-three (II.2, p. 54); the song he sings refers to thieves and a bird «nailed on a branch» (II.5, p. 64); the Spaniards roll dice for his possessions; and Pizarro himself, Herodlike, taunts Atahuallpa: «They'll knock you down but your father the Sun will pick you up again» (II.11, p. 87). At the end of the play, Atahuallpa offers himself as a sacrifice for Pizarro: «If you kill me tonight,» he says, "I will rise at dawn» (II.11, p. 85). The Incans' Chant of Resurrection, with its three cries symbolizes further the three days between Good Friday and Easter morning. 
Shaffer, then, seems to be suggesting Atahuallpa to us as a pagan Jesus. But Pizarro is also given Christlike attributes. Atahuallpa says of Pizarro: «He has been long waited for. If he comes, it is with blessing» (I.3, p. 24), and when Pizarro comes, it is with a wound in his side. Pizarro's story also can be read as a typology of a «second coming» of Christ. Pizarro is in his sixties. In Act I, scene i, Pizarro leaves his home and embarks upon his expedition-ministry. He remains in the forests of Peru for six weeks (roughly forty days) before emerging to travel the road to Cajamarca (Jerusalem). Pizarro tells his men to move over the land as if they were «figures from a Lent Procession,» and indeed the road is lined with eucalyptus trees. However, Pizarro enters his Jerusalem, not to shouts of hosanna, but to grave silence, and it is not he but Atahuallpa who is sacrified.

Atahuallpa's tirne is gone, but the stage directions regarding the sun (it is now Pizarro's head which bears the sun's glow), and Pizarro's sudden ability to do something which neither he nor Atahuallpa had been able to do before (shed a tear) suggest that Atahuallpa's sacrifice has saved, momentarily, one soul. Pizarro carries his joy for a few minutes only before sinking back into despair, but the moment testifies to his later statement that despite everything, there must be «some immortal business surely» in «making whatever God there is» (II.12, p. 90).

Shaffer's association of both Atahuallpa and Pizarro with Jesus seems to suggest that their goals of worship are nobler than the others' in the play, including the goals of the nominal representatives of the Christian Church. It certainly shows Shaffer acknowledging that the major way which his audience conceives of noble worship is through the Christian metaphor, though for Shaffer, as Pizarro discovers, there is no god who can be caught and codified.

There exists in the play a conflict between free will and the will of the group, or the acceptable normative standards. Atahuallpa worships the Sun, but he is doing it freely, whereas the Spanish worship Carlos V and European tradition as if they were law. As Shaffer himself explains, the play becomes a quest to «separate worship from codification» (vii), or an «attempt to draw a 'free man' surging ahead under his own power» (viii). ${ }^{9}$ Pizarro is impressed with Atahuallpa, a man who stands alone without the need to rely on the socializing power of institutions. Atahuallpa teaches Pizarro the value of the self, independent of any external control. The Incan's stoical insistence that proper conduct is relative from one culture to the next impresses Pizarro to such a degree that he renounces his men and proclaims that «Francisco Pizarro casts off Carlos V. Go and tell him» (II.10, p. 81). But even Pizarro, who, like young Martin, loses faith in roles and images, cannot prevent the destruction of free will. Since the group, or the band, is always stronger than any individual force that opposes it, Atahuallpa's death is inevitable.

Pizarro dreams of the God-figure he is seeking. He tells De Soto «You know -strange nonsense: since first I heard of him I've dreamed of him every night» (I.11, p. 44). On the one hand Atahuallpa tries to be God. On the other, Pizarro insist on his god-like role for fear of losing everything. At the same time, and as a self-imposed egotistical god, Pizarro realizes that he must continually play the role of a deity if he is to impress Atahuallpa. Thus when the Spanish enter Incan territory, Pizarro tells his troops : «You're not men any longer, you're Gods now. Eternal Gods each one of you. Two can play this immortality game, my lads» (I.7, p. 35). The «royal hunt of the sun» actually refers to Pizarro's quest for «the Sun,» which implies Atahuallpa, or more 
simply, God. The Spanish leader knows that he uses people and institutions to bolster a favourable, yet false, conception of himself to others. He tells young Martin that «men cannot just stand as men in this world. It's too big for them and they grow scared. So they build themselves shelters against the bigness, do you see? They call the shelters Court, Army, Church» (I.2, p. 22). And he acknowledges that «the world of soldiers is a yard of ungrowable children. They play with ribbons and make up ceremonies just to keep out the rest of the world.» Pizarro becomes the judge, jury, and executioner of what is "proper conduct.» $\mathrm{He}$ justifies the slaughter of the Incas by insisting that he is «to conquer for Christ»; by becoming a god he destroys the freedom of others. The remaining characters represent conflicting forms of idolatry, or the worship of competing gods, and this becomes one of Shaffer's major themes in the play. The very multiplicity of gods in a society makes the purest forms of worship difficult if not impossible. ${ }^{10}$ In The Royal Hunt of the Sun, Shaffer gives us as gods the typical conflicting forces we find described in history books - the state, the church, generals, and economic forces.

Miguel Estete, the Royal Veedor, has made a god of the king of Spain. "General, on this expedition my name is law; it is spoken with the King's authority» (I.2, p. 21), he says to Pizarro. «If you serve a King you must kill personal ambition. Only then can you become a channel between the people and its collective glory -which otherwise it would never feel. In Byzantium Court, officials were castrated to resemble angels» (I.5, p. 28).

Martin Ruiz has made chivalry his god. He represents one of the more moving studies of worship in the play. Martin's loss of his god preceeds and, in a sense, prepares the way for Pizarro's loss of Atahuallpa. In his first speech, Young Martin explains how he used to «lie up in the hayloft for hours reading my Bible -Don Cristobal on the rules of Chivalry» (I.1, p. 14). Martin not only seeks to «serve» Pizarro, a famous general for whom, ironically, chivalry is a «closed book,» but insists on calling him «my lord.» Pizarro was to him «my altar, my bright image of salvation.» Martin's journey to Cajamarca becomes, then, like Pizarro's a pilgrimage which ends in the loss of a god. Martin's leap into manhood comes with his discovery that his god is not worthy of worship. "Well, what are you staring at, Little Lord Chivalry. Get out!," Pizarro screams at Martin when he is going to betray his promise to Atahuallpa. «He trusts you, sir,» insists Young Martin, to which the false idol replies, «Trust: what's that? Another word. Honour ... glory ... trust: your word -Gods!» (II.7, p. 74). And then Old Martin addresses the audience to tell us: «I went into the night -the cold high night of the Andes, hung with stars like crystal apples (a reference to the fall) -and dropped my first tears as a man. My first and last. That was my first and last worship too. Devotion never came again» (II.7, p. 74), to end up with the expression of his great disillusion: «The only wish in my life is that $I$ had never seen him» (I.1, p. 14).

Then, in Pizarro himself we can trace a number of different kinds of "gods» he has embraced and abandoned by the age of sixty-three. As he makes clear in act I, scene i, wealth was his god earlier in life, and Pizarro could once have been bought for a «petty farm, two rocky fields and a Señor to my name» (I.1, p. 19). Pizarro has put this god behind him, however, and at the opening of the play seems to have taken "fame" as his god: «I'm going to get me a name that won't ever be forgotten. A name to be sung here for centuries in your ballads . . . The old pigherd lumbering after fame" (I.1, p. 19). Much later in the play, act II, scene x, when De Soto tells Pizarro he must let 
Atahuallpa go, fame as god once again seems to come to the fore. «A tiny army is wiped out in five minutes, and the whole story is lost for always,» Pizarro responds, «later someone else will conquer Peru and no one will even remember my name» (II.7, p. 80). Yet a few speeches later, Pizarro denies the force of even this god in his life "-I'll never live to hear [the ballads]. What do I care? What does it matter?» He also casts off the state as god. Ironically, what remains for this atheist is one last hope that a pagan sun god can «cheat» the encroaching shadow of time.

Christianity as a form of worship receives more complex treatment in The Royal Hunt of the Sun. We recognize the above idolatries not only because of their expression in Christian semiology, but because Shaffer distributes divers aspects of Christian worship itself among several major characters. The worship of the Christian God is divided between two priests, but throughout the play, Shaffer carefully distinguishes De Nizza from the other representative of the Church who accompanies Pizarro in his adventure. Fray Vicente de Valverde, the Dominican Chaplain to the expedition, a greedy and corrupt character, represents the Church as hypocritical militant God: «You are the huntsmen of God,» he tells the Spanish soldiers, «The weapons you draw are sacred! Oh, God, invest us all with the courage of Thy unflinching Son. Show us our way to beat the savage out of his dark forests on the broad plain of Thy grace" (I.2, p. 20). Valverde thus speaks for the Pope and for the institution of the Church as highest god. His assistant, the Franciscan Friar Marcos De Nizza, speaks as the representative of Christian philosophy, and this philosophy is based on the freedom to want, suffer, hope and love, yet it ultimately fails in practice when its exponent, De Nizza, fails to recognize the love of a pagan (Atahuallpa) for Pizarro.

Neither priest is depicted as a sympathetic representative of the Christian religion though De Nizza is untainted by Valverde's sins. Perhaps one might say against him that he is lacking in compassion, but he is sincere. More important, he is intelligent, knows Pizarro's heart, and is able to assert a countervailing doctrine that balances the Inca's influence. De Nizza is given the most arresting speech in the play. In response to Pizarro's admiration for the Indians who live as «part of nature» with «no hope and no despair,» De Nizza replies:

And no life. Why must you be so dishonest? You are not only part of nature, and you know it. There is something in you at war with nature: there is in all of us. Something that does not belong in you the animal. What do you think it is? What is this pain in you that month after month makes you hurl yourself against the cage of time? (II.10, p. 83).

De Nizza identifies the pain as God, the spark of divinity within that separates man from nature. This is significant thematically, and it has an important impact on Pizarro, who is now caught between two equally potent forces: naturalism and a Christian theology that reclaims his attention on De Nizza's grounds. Pizarro acknowledges his special pain, even nourishes it, but the only faith that he is able to claim at the end of the play is this: "The sky knows no feelings, but we know them, that's sure" (II.12, p. 90). Confused and disillusioned, Pizarro is compelled to relinquish his religious quest. He dies joyless and cold «between two darks: blind eyes and a blind sky,» his journey incomplete.

Shaffer also seems to require dramatically a De Soto figure to encourage the God-hunter, to supply moral and ethical impetus for the quest or hunt, and to provide 
an unchallenged symbol of the status quo. He is a very enigmatic creation and Shaffer describes him as «his whole air breathes an unquestioning loyalty -to his profession, his faith, and to accepted values» (I.1, p. 14). He is depicted as an admirable and noble character, and yet Shaffer would have us believe that he has the least difficulty or desire regarding worship, and, therefore, lacks both the insight and passion of Pizarro.

The pattern of internal division we find in the major characters -Pizarro's instinctive sense of feeling somehow incomplete- provides for an excellent dramatic material. Shaffer's characters are strikingly contemporary in their misgivings. He seems to have struck a resonating chord with his ability to project publicly our collective impulse to rebel against the raggedness of modern life, and his characters express a deep longing for self integration, which has broad appeal. Pizarro, appeals to us as a cynic burning to surmount his corrosive experience of politics: "Give me a reason that stays noble once you start hacking off limbs in its name. There isn't a cause in the world to set against this pain. Noble's a word. Leave it for the books» (I.2, p. 23).

The Royal Hunt of the Sun has been written for spectacular staging, to realize that kind of «total theatre.» Shaffer has no peer in exploiting the theatre's full range of expressive means. He takes particular interest in the mise en scene, and aims for dramatic clarity and visual effect. Perhaps what we ought to value most in Shaffer is his penchant for transforming private experience to gorgeous spectacle, for in this enterprise he is supreme. In The Royal Hunt of the Sun, the result is a powerful union of form and content on the modern stage and a strong representation of the effectiveness of ritualistic drama.

\section{Notes}

1. Eugene O'Neill, quoted by Joseph Wood Krutch, «Introduction» to Nine Plays by Eugene O'Neill (New York: Random House, 1954), p. xvii.

2. Peter Shaffer, Amadeus (London: Penguin Plays, 1980), p. 27.

3. Wayne Paul Lawson, The Dramatic Hunt: A Critical Evaluation of Peter Saffer's Plays, dissertation (Ohio State University, 1974), p. 120.

4. Peter Shaffer, The Royal Hunt of the Sun (New York: Stein and Day, 1965).

5. Antonin Artaud, Le théatre et son double (Paris: Éditions Gallimard, 1964), p. 191.

6. Peter Shaffer, The Royal Hunt of the Sun (4).

7. Antonin Artaud, p. 128.

8. Peter Shaffer, The Royal Hunt of the Sun (London: Penguin Plays, 1964).

9. Peter Shaffer, The Royal Hunt of the Sun (4).

10. Shaffer admitted this possibility in an interview with John Russell Taylor; see Plays and Players (11 April 1964), p. 12.

\section{Bibliography}

Artaud, Antonin. Le thêatre et son double. Paris: Éditions Gallimard, 1964. Cole, Tobin, ed. Playwrights on Playwriting. London: Methuen Publications, 1983. Elsom, John. PostWar British Theatre. London: Routledge and Kegan Paul, 1976. 
Hatlen, Theodore W. Orientation to the Theatre. Englewood Cliffs, N. J.: Prentice-Hall International Inc., 1981.

Kerensky, Oleg. The New British Drama. New York: Tapingler Publishing Co., 1977.

Krutch, Joseph Wood. Nine Plays by Eugene O'Neill. New York: Random House, 1954.

Lawson, Wayne Paul. The Dramatic Hunt: A Critical Evaluation of Peter Shaffer's Plays. Dissertation. Ohio State University, 1974.

Plays and Players, (11 April 1964).

Pree, Barry. Behind the Scenes. Joseph F. McCrindle, ed. London: Pitman, 1971.

Shaffer, Peter. The Royal Hunt of the Sun. London: Penguin Plays, 1964.

. The Royal Hunt of the Sun. New York: Stein and Day, 1965. . Amadeus. London: Penguin Plays, 1980. 